Ekonomia - Wroclaw Economic Review 25/4 (2019)

Acta Universitatis Wratislaviensis

No 3949

DOI: $10.19195 / 2658-1310.25 .4 .2$

Julitta Koćwin

ORCID: 0000-0002-1128-3830

Uniwersytet Wrocławski

jk.prawo.uni.wroc.pl@gmail.com

\title{
Pracownicze Plany Kapitałowe w praktyce. Opłacalność programu - jego główne wady i zalety
}

Artykuł nadesłany: 11.12.2018; artykuł zaakceptowany: 12.06.2019

Kody klasyfikacji JEL: G2

Keywords: PPK, third pillar, pension, pension funds, savings

\section{Abstract \\ Employee capital plans in practice. The program's profitability - its main advantages and disadvantages}

The aim of the article was to present the basic assumptions of the Pracownicze Plany Kapitałowe program and to draw attention to the issue of its success and profitability for future pensioners. This program advertised as a pro social one by the ruling party in fact may not be one. The article tried to find the answer to the question of what are the intentions of the government and what the main purpose of the program is. Is it aimed at financial security for future pensioners or at feeding the declining financial market? So far, attention was drawn to the main advantages and disadvantages of this program, analyzed from the point of view of "who will benefit the most from it."

\section{Wstęp}

W czasie VIII kadencji Sejmu RP problem przyszłych emerytur i zabezpieczenia emerytalnego obywateli na przyszłość był dość często podejmowany przez polityków PiS, kwestia ta była także na bieżąco omawiana przez media. Nowe pomysły rządu i wdrażane projekty mają na celu zabezpieczenie emerytalne osób, które nie zadbały o swoją przyszłość finansową w okresie osiągania wieku emerytalnego, a także zachęcenie do uzupełnienia obowiązkowego systemu emerytalnego o dodatkowe środki pochodzące z indywidualnych oszczędności z III filaru. 
W 2018 roku (28.08.2018) rząd PiS przygotował nowy projekt ustawy o Pracowniczych Planach Kapitałowych (PPK), mający na celu wspomożenie systemu emerytur z ZUS, czego przesłanką była okoliczność, że nie sprawdziły się dodatkowe formy oszczędzania w III filarze, które nie dość że nie cieszyły się zainteresowaniem obywateli, to jeszcze nie osiągnęły pożądanego przez rząd poziomu rozwoju.

Konstruując projekt ustawy o PPK, rząd tym razem wyciągnął wnioski z niepopularności dotychczasowego zainteresowania oszczędzaniem w III filarze i zdał sobie sprawę, że bez zachęt o charakterze fiskalnym i finansowym nie nastąpi wzrost tego rynku - dlatego też program PPK został wsparty finansowymi zachętami ze strony państwa. Mimo to PPK stanowią kolejny pomysł rządu, który ponownie został zaakceptowany, jak jego poprzednicy: OFE (II filar) i IKE, IKZE i PPE (III filar), przez posłów, z których wielu nie ma większej wiedzy na temat finansów od swoich wyborców, co jednak nie powstrzymało ich przed tworzeniem nowego programu.

Celem artykułu jest przedstawienie podstawowych założeń programu PPK (,nowej reformy emerytalnej”) oraz zwrócenie uwagi na możliwość jego powodzenia oraz opłacalności dla przyszłych emerytów. Wychodząc z tej przesłanki, w tekście starano się znaleźć odpowiedź na następujące pytania:

1. Jakie są intencje rządu i jaki jest główny cel tego programu?

2. Czy ma on na celu zabezpieczenie finansowe przyszłych emerytów, czy też zasilenie podupadającego rynku finansowego?

3. Czy na pewno jest on prospołeczny?

4. Kto rzeczywiście najwięcej na nim skorzysta?

Punktem wyjściowym badań jest przedstawienie aktualnej sytuacji na polskim rynku pracy oraz na rynku otwartych funduszy emerytalnych, a także wskazanie, jak ,nowa reforma emerytalna” wpłynie na trendy rozwojowe na obu rynkach oraz czy będą one miały wpływ na polski rynek kapitałowy. Rozstrzygnięcie tych kwestii wymagało skoncentrowania się w badaniach na następujących problemach:

— przedstawienie rządowej koncepcji programu PPK;

— dokonanie oceny jego opłacalności oraz wskazanie mocnych i słabych stron przyjętych rozwiązań, uwzględniające interesy pracodawców, pracowników oraz państwa odpowiedzialnego za zrównoważony rozwój.

\section{Teoretyczny aspekt badań}

Wprowadzenie nowych rozwiązań emerytalnych (PPK) do praktyki życia społeczno-gospodarczego zawsze wymaga rozpatrzenia ich mocnych i słabych stron. W dłuższym czasie ich funkcjonowania można określić je, wykorzystując metodologię badań ilościowych i jakościowych. Jednak w początkowym okresie ich 
wdrożenia szczególnie wynikające $\mathrm{z}$ nich zagrożenia określić można metodami badań jakościowych. Ich wyniki pozwalają na wprowadzenie korekt do przyjętych rozwiązań i/lub ich wdrożenie, aby nie przyniosły nieprzewidzianych ujemnych skutków społecznych i ekonomicznych. W badaniach szczególną uwagę zwrócono na potencjalne negatywne konsekwencje wprowadzanej ustawy.

\section{Metodologia badań}

W prezentowanym opracowaniu wykorzystano metodologię badań jakościowych (metodę studium przypadku) w celu analizy źródeł pierwotnych (dokumentu) oraz źródeł wtórnych (publikacje) związanych z podjętym problemem badawczym. Umożliwiło to sformułowanie na podstawie ich dedukcji tez i ogólnych wniosków.

W badaniach uwzględniono kontekst ekonomiczny, prawny i polityczny wpływający na podjęte rozwiązania zawarte w PPK przy zachowaniu obiektywności i intersubiektywności badań, posługując się dostępnymi technikami zbierania informacji. Dlatego też w badaniach wykorzystano materiały źródłowe, takie jak projekt ustawy, ocenę skutków regulacji, opinie ekspertów, oraz literaturę związaną z podjętym problemem analizy.

\section{Reforma emerytalna według koncepcji PiS}

W 2014 roku w wieku produkcyjnym było w Polsce 63\% całej populacji. Szacuje się, że w 2050 roku będzie w kraju 56\% takich osób. ZUS ostrzega, że za pięć lat na wypłaty świadczeń emerytalnych może zabraknąć $400 \mathrm{mld}$ zł. Pieniądze te muszą jednak bezwzględnie znaleźć się w budżecie. Powstała luka budżetowa jest skutkiem obniżenia wieku emerytalnego (zrealizowania jednej z obietnic wyborczych PiS) oraz zachęcania do przechodzenia na wcześniejsze emerytury. W 2018 roku świadczenia emerytalne zaczęła pobierać rekordowa liczba uprawnionych. Należy podkreślić, że w 2017 roku na emeryturę przeszło aż 417 tys. osób, co było największą liczbą od 1989 roku. Jeszcze cztery lata temu na emeryturę przechodziło rocznie około 120 tys. osób. Według prognoz rządu wcześniejszy wiek emerytalny miał kosztować w 2017 roku 10 mld zł, jak się jednak okazało — kwota ta była wyższa o kilka miliardów.

W celu pozyskania dodatkowych środków finansowych niezbędnych do sfinansowania obniżenia wieku emerytalnego rząd zlikwidował limit składek na ZUS dla osób z zarobkami powyżej 10 tys. zł. Nadal jest ich jednak za mało. Należy przypuszczać, że po brakujące pieniądze — jak przewiduje Wiktor Wojciechowski, główny ekonomista Plus Banku — rząd sięgnie do OFE i przekaże je do zarządzanego przez ZUS Funduszu Rezerwy Demograficznej. Z kolei eksperci zapytani przez „Gazetę Wyborczą” o sposób likwidacji luki budżetowej dotyczącej 
brakujących środków finansowych odpowiedzieli, że wyjściem z tej sytuacji jest likwidacja przywilejów emerytalnych górników, mundurowych i rolników oraz powrót do progu emerytalnego 67 lat (Skąd wziąć pieniądze..., 2018).

Premier Mateusz Morawiecki miał świadomość, że zmniejszenie się liczby osób pracujących i zwiększenie liczebności emerytów stworzy problemy, dlatego przed wejściem w życie obniżki wieku emerytalnego opracował „Program 10 tysięcy plus". Zgodnie z jego projektem osoby chcące dłużej pracować i w ten sposób opóźnić swoje przejście na emeryturę otrzymałyby jednorazową wypłatę w wysokości 10 tys. zł za dwa lata opóźnienia i 5 tys. zł za każdy kolejny rok. W ten sposób wypracowaliby więcej pieniędzy, niż trafiłoby do nich z budżetu. Pomysł został jednak skrytykowany przez PiS, ponieważ premia trafiałaby do osób, które chcą pracować dłużej, i otrzymałyby one wyższe emerytury, a co za tym idzie nie wszedł w życie (Frączyk, 2017). To argument potwierdzający, że rząd PiS nie wspiera osób aktywnych zawodowo.

Kolejnym pomysłem premiera Morawieckiego jest emerytura obywatelska, o której po raz pierwszy premier mówił pod koniec 2016 roku. Emerytura ta obejmowałaby pięć filarów: od państwa 1000 zł miesięcznie dla każdego, składki płacone od pensji, pieniądze odkładane przez zakład pracy, program „Silna rodzina” oraz własne oszczędności (Emerytury..., 2017).

Ekonomiści przestrzegają jednak, że wprowadzenie emerytury obywatelskiej spowoduje zmniejszenie składek lub ich całkowitą likwidację, a wówczas zabraknie pieniędzy na wypłaty bieżących świadczeń. Ekspert ubezpieczeniowy z Konfederacji Lewiatan - Jeremi Mordasewicz — uważa, że wprowadzenie takiego systemu osłabi motywację do pracy, ponieważ większość społeczeństwa, mając zagwarantowaną emeryturę obywatelską, nie będzie pracować. Dodatkowo istnieje niebezpieczeństwo, że z 10\% zabieranego z emerytur osób pracujących zrobi się 20 lub 30\% (Wiktorowska, 2018b).

Pomysł emerytury obywatelskiej jest wyjątkowo niesprawiedliwym przedsięwzięciem osłabiającym skłonność do pracy, „bo po co pracować, skoro to inni złożą się na naszą emeryturę"; może on w dodatku spowodować ucieczkę w szarą strefę i ukrywanie dochodów z myślą „dlaczego osoby pracujące mają składać się na emerytury »darmozjadów «".

Z kolei konceptem premiera Morawieckiego, który niebawem wejdzie w życie, są Pracownicze Plany Kapitałowe (PPK). Projekt ustawy o PPK został opracowany przez Ministerstwo Finansów we współpracy z Polskim Funduszem Rozwoju. Prace nad reformą emerytalną trwały od dwóch lat. Stanowi ona kolejną wielką reformę emerytalną, podobną do tej sprzed 20 lat, wprowadzającej Otwarte Fundusze Emerytalne (Popiołek, Kostrzewski, 2018). Tym razem jednak rząd zapewnił, że oszczędności gromadzone na nowych kontach emerytalnych (PPK) będą zapisane na prywatnych indywidualnych kontach pracowników, będą mo- 
gły być dziedziczone, a także będzie możliwość wypłaty z nich środków w każdej chwili. Zdaniem rządu ma to zachęcić do oszczędzania na przyszłą emeryturę.

Program PPK był konsultowany z różnymi grupami zawodowymi w ramach Rady Dialogu Społecznego, to jest z: organizacjami pracodawców i związkami zawodowymi (Solidarność, Forum) (Boratyński, 2018). Został oparty na doświadczeniach międzynarodowych, sprawdzonych w kilku krajach, na przykład w Wielkiej Brytanii, gdzie 80\% obywateli gromadzi kapitał na emeryturę na kontach emerytalnych tworzonych przez pracodawców. Z tym że w Wielkiej Brytanii przygotowania do wprowadzenia (wdrożenia) podobnego systemu trwały sześć lat (Pracownicze Plany Kapitałowe..., 2018), podczas gdy polski rząd początkowo planował wprowadzić program już od 1 stycznia 2019 roku.

We wcześniejszym projekcie ustawy Ministerstwo Finansów zwalniało z zakładania PPK tych przedsiębiorców, którzy założyli u siebie Pracownicze Programy Emerytalne (PPE). Program PPE działa już od wielu lat i polega ogólnie na tym samym co wprowadzane PPK — to system oszczędzania na emeryturę z pracodawcą, polegający na tym, że pracownik wpłaca część składki, a pracodawca dorzuca część od siebie, z tą różnicą, że w PPE nie ma dopłat ze strony państwa.

Należy jednak zaznaczyć, że PPE nie stały się powszechne w Polsce; obecnie funkcjonują w zaledwie około tysiącu firm, aczkolwiek w ostatnim czasie zakładanie PPE znacząco przyspieszyło. W projekcie nowej ustawy przyjęto bowiem, że pracodawca może uwolnić się od obowiązku tworzenia PPK, jeśli do końca 2018 roku zakład będzie miał PPE o określonych parametrach (bierze w nim udział 25\% pracowników, a składka miesięczna wynosi min. 3,5\%). Wcześniej projekt nie przewidywał żadnej końcowej daty. Procedura tworzenia PPE w praktyce trwa co najmniej kilkanaście tygodni, gdyż składa się na nią postępowanie administracyjne przed Komisją Nadzoru Finansowego (KNF), następnie wybór usługodawcy PPE, zawarcie umów i na koniec wdrożenie. Dlatego nie ma szans, aby pracodawca, podejmując decyzję o utworzeniu PPE we wrześniu 2018 roku, miał możliwość uwolnić się od utworzenia PPK. Wskazuje to dobitnie na intencje pomysłodawców PPK, którzy chcą doprowadzić do likwidacji dobrze rozwijających się obecnie PPE (Popiołek, Kostrzewski, 2018).

Oferta PPK kierowana jest do osób zatrudnionych, natomiast dla samozatrudnionych zaplanowano podwyższenie limitu na Indywidualnym Koncie Zabezpieczenia Emerytalnego (IKZE) z 1,2 do 1,8 przeciętnego wynagrodzenia miesięcznego w gospodarce narodowej (Krześniak-Sajewicz, 2018).

Sejm 4 października 2018 roku przyjął rządowy projekt ustawy o Pracowniczych Planach Kapitałowych. Mają one stanowić kolejny — po świadczeniach z ZUS i dobrowolnym oszczędzaniu w ramach III filaru na wcześniej wspomnianych PPE, Indywidualnych Kontach Emerytalnych (IKE) czy Indywidualnych Kontach Zabezpieczenia Emerytalnego (IKZE) — filar systemu emerytalnego. 


\section{Pracownicze Plany Kapitałowe}

W zamierzeniach rządu PPK i objęte programem środki (wpłacane przez pracownika, a także dopłacane przez pracodawcę i z budżetu państwa) mają stanowić dobrowolny, w pełni prywatny i długoterminowy program oszczędnościowy dla pracowników oraz system budowy oszczędności emerytalnych, w którym może uczestniczyć każdy pracujący obywatel. Ma to być także kolejny program zabezpieczenia społecznego w dłuższym czasie.

Celem programu ma być podniesienie poziomu bezpieczeństwa finansowego obywateli i ich rodzin oraz wzrost poziomu oszczędności emerytalnych, a także wyższe świadczenia, co w efekcie ma prowadzić do dobrobytu obywateli. Rząd podkreśla, że PPK nie mają nic wspólnego z systemem emerytalnym (nie są ściśle powiązane z emeryturą), ponieważ jest to program oszczędnościowy, mający funkcjonować obok już działającego systemu, zgodnie z założeniem, że gromadzone w ten sposób pieniądze mają być przeznaczone na emeryturę. Intencją rządu jest jedynie stworzenie warunków, w których obywatele mieliby więcej pieniędzy na starość, które sami by zaoszczędzili. Początek obowiązywania nowych przepisów zaplanowano na 1 lipca 2019 roku (Rewolucja w emeryturach..., 2018).

Zgodnie z projektem program obejmie ponad $11 \mathrm{mln}$ osób $(9 \mathrm{mln}$ w sektorze przedsiębiorstw prywatnych i $2 \mathrm{mln}$ w sektorze finansów publicznych). System zakłada, że programem automatycznie zostaną objęci wszyscy pracujący Polacy, niezależnie od formy zatrudnienia (z wyjątkiem samozatrudnionych), w wieku od 19 do 55 lat, za których odprowadzane są składki na ubezpieczenie emerytalne (Ceglarz, Janoś, 2018).

Zapowiadana w projekcie ustawy wysokość składek oraz zachęt fiskalnych w ramach PPK przedstawia się następująco:

— jednorazowa składka (dopłata) powitalna ze strony państwa — 250 zł (do końca 2020 roku);

— coroczna dopłata od państwa - 240 zł, równa dla każdego;

- podstawowa składka pracodawcy — 1,5\% podstawy składek na ubezpieczenie emerytalne i rentowe (stawka ta będzie dodatkowym kosztem zatrudnienia pracownika);

— dodatkowa dobrowolna składka pracodawcy — do 2,5\% podstawy składek na ubezpieczenie emerytalne i rentowe;

— podstawowa składka pracownika — $2 \%$ podstawy składek na ubezpieczenie emerytalne i rentowe;

- dodatkowa dobrowolna składka pracownika — do 2\% podstawy składek na ubezpieczenie emerytalne i rentowe (Rzadowy projekt..., 2018, art. 26-27, 31-32).

Łączna minimalna składka, to jest odprowadzana przez pracodawcę i pracownika, może wynieść 3,5\%, a maksymalnie $8 \%$ wynagrodzenia (4\% od pracownika, 4\% od pracodawcy), jednak tylko za zgodą pracownika i pracodawcy. Zasady pobierania składek prezentuje tabela 1 . 
Tabela 1. Wysokość i struktura składek w PPK

\begin{tabular}{|c|c|c|}
\hline \multicolumn{3}{|c|}{ Wysokość składek w PPK } \\
\hline Pracownik & Pracodawca & Państwo \\
\hline $\begin{array}{c}\text { 2 lub 4\% pensji brutto - } \\
\text { pobierane od pensji netto } \\
\text { (na rękę) }\end{array}$ & 1,5 lub 4\% pensji brutto & $\begin{array}{r}240 \text { zł za każdy rok } \\
\text { uczestnictwa w PPK }\end{array}$ \\
\hline
\end{tabular}

Źródło: opracowanie własne.

Od momentu zapisu do programu od pensji brutto pracownika będzie pobierane przynajmniej 2\% (dla zarabiających więcej niż pensja minimalna, czyli 2100 zł), jednak pobierane już od pensji netto, to jest od wypłaty na rękę. Zasada ta w praktyce oznacza niższą pensję co miesiąc.

Projekt ustawy zakłada, że najmniej będą oszczędzać najgorzej zarabiający, to jest zarabiający mniej niż 120\% pensji minimalnej (obecnie około $2500 \mathrm{zl}$ ) zamiast $2 \%$ ulokują na koncie $0,5 \%$ swojego wynagrodzenia (Rządowy projekt..., 2018, art. 27), co oznacza dla nich dużo niższe emerytury.

Według założeń w ciągu dziesięciu lat rząd planuje na prywatne, dobrowolnie zakładane konta emerytalne wpłacić 35-40 mld zł lub więcej. Sposób zarządzania tymi środkami przez PPK będzie pod ścisłym nadzorem państwowym.

W opinii rządu ustawa o PPK jest bardzo korzystna dla wszystkich pracowników, a także dla pracodawców. Zdaniem Morawieckiego program jest prospołeczny i najwięcej mają na nim skorzystać najmniej zarabiający (JB, 2018a).

Na uwagę zasługuje zawarte w PPK rozwiązanie, które zakłada, że nawet jeśli pracownik nie chce oszczędzać od początku obowiązywania ustawy, to i tak raz na cztery lata (wcześniej projekt przewidywał zapis co dwa lata) zostanie ponownie automatycznie zapisany do PPK. Paweł Borys, prezes Polskiego Funduszu Rozwoju oraz przewodniczący rady nadzorczej Banku Gospodarstwa Krajowego, uważa, że ta logika wynika z ekonomii behawioralnej Richarda Thalera. Zgodnie z jej założeniami ludzie nie podejmują odpowiednich decyzji w zakresie finansów osobistych, zdrowia i edukacji, nie patrzą długoterminowo, przekładając konsumpcję nad oszczędności. W związku z tym państwowa polityka publiczna powinna dostarczać bodźce do optymalnych wyborów. Pracujący będą jednak mieli wolny wybór oszczędzania w PPK — na każdym etapie (w dowolnym momencie) mogą zrezygnować (wycofać się), wypłacić pieniądze i ustawa obecnie nie przewiduje za to kar. Ale pod pewnymi warunkami. W takiej sytuacji składka potrącana z wynagrodzenia netto pracownika jest mu oddawana w całości, podczas gdy kwoty zachęt (dopłata roczna 240 zł i opłata powitalna 250 zł) wracają do budżetu państwa. Z kolei kwota przekazana przez pracodawcę jest mu zwracana po potrąceniu 30\%, które trafiają na konto emerytalne pracownika w ZUS. Warunkiem nieuczestniczenia w PPK będzie konieczność złożenia właściwych dokumentów w miejscu zatrudnienia. Deklarację będzie trzeba ponawiać co cztery lata. W związku z tym raz na cztery lata pracownik powinien być informowany, że w zakładzie pracy 
funkcjonuje PPK, którego może być uczestnikiem, ale jeśli nie jest zainteresowany, to żadne pobieranie składek nie nastąpi (Osiecki, Godusławski, 2018).

Pieniądze gromadzone na indywidualnym koncie PPK będą inwestowane przez wyspecjalizowane instytucje finansowe. Będą nimi zarządzać Towarzystwa Funduszy Inwestycyjnych (TFI), Powszechne Towarzystwa Emerytalne lub ubezpieczyciele, a ich ewidencję będzie prowadzić Polski Fundusz Rozwoju. Kontrolę nad ich funkcjonowaniem będzie sprawować KNF. Wyborem odpowiedniej instytucji do zarządzania środkami za pracowników zajmą się pracodawcy wspólnie ze związkami zawodowymi działającymi w firmie. Przy zmianie miejsca pracy pracownik zostanie automatycznie przeniesiony do funduszu wybranego przez nowego pracodawcę, jednakże będzie mógł zdecydować, czy dotąd zgromadzone środki mają zostać przeniesione do nowego PPK, czy pozostaną w poprzednim (Ceglarz, Janoś, 2018).

Program ma być realizowany etapami. Pierwsze do PPK trafią osoby, które pracują w firmach zatrudniających ponad 250 osób. Następnie co pół roku programem będą obejmowane kolejne przedsiębiorstwa. Od 1 stycznia 2020 roku PPK zostanie wprowadzony w firmach zatrudniających 50 osób, od połowy 2020 roku pojawi się w firmach zatrudniających tylko 20 pracowników, a od 1 stycznia 2021 roku program wejdzie do placówek zatrudniających kilku pracowników i jednostek administracji publicznej. Jednocześnie ustawa przewiduje grzywnę w wysokości od 1000 do 1 mln zł dla przedsiębiorców, którzy nie wywiążą się z obowiązku dokonywania wpłat do PPK (Rząd przyjąt projekt..., 2018).

W ocenie skutków regulacji projektodawcy wskazali, że PPK są skierowane do 11,4 mln osób, jednak Ministerstwo Finansów zakłada, że na systematyczne oszczędzanie zdecyduje się około $75 \%$ osób (wskaźnik partycypacji), co oznaczałoby, że do programu PPK przystąpi 8,6 mln osób (Ocena..., 2018, 11).

\subsection{Wypłata środków z PPK}

Moment wypłaty środków z PPK przypada na wiek 60 lat, a nie na wiek emerytalny (60 kobiety i 65 mężczyźni). Jest to związane z regulacją unijną dotyczącą równego traktowania kobiet i mężczyzn na rynku pracy, obejmującego również kwestię wieku emerytalnego. Ponieważ nie można było zastosować ustawowego wieku emerytalnego, ustawodawca zrównał go do niższego wieku kobiet.

Po ukończeniu tego wieku oszczędzający będzie mógł zdecydować się na jednorazową wypłatę $25 \%$ zgromadzonych pieniędzy bez konieczności opłacenia podatku. Ponieważ PPK ma być zabezpieczeniem dla przyszłych emerytów, wprowadzono zachętę, aby pozostałe minimum 75\% środków przeznaczono na miesięczne wypłaty w okresie minimum dziesięciu lat, tak by zaoszczędzone pieniądze nie zostały od razu skonsumowane. Zebraną kwotę można także rozłożyć na więcej rat lub zdecydować się na dożywotnie wypłaty. Tu bodźcem znów jest zwolnienie oszczędności z podatku od zysków kapitałowych. Należy przy tym pamiętać, że 
oszczędności z PPK pochodzą z wynagrodzenia netto i nie są od nich wcześniej pobierane żadne podatki.

Wcześniejsze (niż dziesięć lat od rozpoczęcia ustawowej wypłaty środków z PPK) wycofanie $100 \%$ zgromadzonych środków będzie oznaczało konieczność opłacenia podatku od zysków kapitałowych (tak zwanego podatku Belki) w wysokości $19 \%$, ale tylko od zysków - nie obejmuje on składki, którą się wpłacało (Ratajczak, 2018).

W PPK preferowane są wypłaty (świadczenia) okresowe z uwagi na zmiany demograficzne oraz nieoferowanie przez sektor ubezpieczeń produktów ubezpieczenia dożywotniego ze względu na ryzyko tak zwanej odwrotnej selekcji. Szacuje się, że przez następne 30-40 lat populacja Polski może zredukować się o $5 \mathrm{mln}$ osób, na rynku pracy ubędzie ponad $6 \mathrm{mln}$ zatrudnionych, a liczba emerytów zwiększy się o ponad $3 \mathrm{mln}$. Przyszłe pokolenia będą więc ponosiły duże obciążenia finansowe, by utrzymać I filar systemu emerytalnego (Osiecki, Godusławski, 2018).

Ustawa przewiduje także możliwość wcześniejszego skorzystania ze środków zgromadzonych w PPK, umożliwiając dostęp do nich w trakcie trwania programu i przeznaczenie ich na cele inne niż emerytura. Oszczędności te będzie można jednorazowo pobrać na sfinansowanie wkładu (udziału) własnego przy zakupie jednego mieszkania lub budynku mieszkalnego (domu). Pieniądze trzeba będzie jednak zwrócić w następnych latach na PPK — po pięciu latach „przerwy” oszczędzający będzie miał dziesięć lat na spłatę środków.

Inna możliwość dopuszcza, że będzie można wnioskować o wypłatę maksymalnie 25\% środków gromadzonych na PPK w sytuacji trwałej niezdolności do pracy lub poważnych problemów zdrowotnych (poważnej choroby) oszczędzającego lub członka jego rodziny (współmałżonka lub dziecka). Pieniądze wykorzystane w tym celu nie będą musiały być zwracane na PPK. W wypadku śmierci osoby gromadzącej oszczędności w PPK dotychczas uzbierane środki mają być w pełni dziedziczone przez jej najbliższych (Rządowy projekt..., 2018, art. 98, 101) — po śmierci oszczędzającego trafią one do spadku.

\section{PPK w praktyce - opłacalność programu}

Przedstawienie konkretnych danych na temat tego, ile przyszły emeryt otrzyma z PPK, jest niemożliwe. Kapitał zgromadzony w PPK będzie bowiem inwestowany przez Towarzystwa Funduszy Inwestycyjnych, a jego wartość będzie zależeć od stopy zwrotu z tych inwestycji. Utrzymanie jej na stałym poziomie przez długi czas nie jest możliwe, gdyż w światowej gospodarce, a także w kraju może pojawić się kryzys. Dodatkowo PPK mają być dla większości programem oszczędnościowym gwarantowanym na blisko 40 lat. Należy również uwzględnić, że składki odprowadzane od pensji w perspektywie czasu będą się znacznie zmieniać. Przez 
ten okres pensje wzrosną, ale jednocześnie w tym samym czasie będą rosnąć ceny produktów i usług (wystąpią procesy inflacyjne) - 2000 zł za 40 lat nie będzie zatem oznaczać siły nabywczej 2000 zł na dziś. Najwięcej na PPK mogą skorzystać odkładający jak najdłużej, gdyż (1) uzbierają znaczny kapitał własny, (2) sporo dopłaci im pracodawca, (3) czas inwestycji będzie dłuższy (Ratajczak, 2018).

Wielkość stopy zastąpienia (stosunek wysokości pierwszej emerytury do wysokości ostatniej pensji) w okresie dziesięciu lat wypłaty można tylko szacować. Przy okresie oszczędzania 40 lat i składce 3,5\% relacja świadczenia do ostatniej pensji wyniesie $25 \%$. Prognozując, że emerytury z ZUS w przyszłości będą na poziomie 35\% ostatniej pensji, świadczenie z PPK będzie bardziej zauważalne. Dla osoby oszczędzającej $8 \%$ stopa zastąpienia rośnie bowiem aż o $45 \%$. Aby nie obniżyć drastycznie poziomu życia po przejściu na emeryturę, stopa zastąpienia powinna jednak wynosić 50-60\% (Osiecki, Godusławski, 2018).

\section{Obiektywnie o PPK — słabe i mocne strony programu}

\subsection{Automatyczny zapis pracowników do programu długoterminowego oszczędzania}

Polacy mają bardzo niskie oszczędności w wartościach bezwzględnych oraz w relacji do PKB na tle innych krajów Europy. Powody niewykształcenia nawyku oszczędzania są różne, jednak wiele z nich jest racjonalnych. Po obniżeniu wieku emerytalnego przez rząd PiS i możliwości przechodzenia na wcześniejszą emeryturę wielu seniorów zostało skazanych na egzystencję z najniższymi świadczeniami. Emerytury z ZUS powinny zostać uzupełnione pieniędzmi z innych źródeł, jednak popularność III filaru z uwagi na jego nieopłacalność jest niewielka, a aktywne konta emerytalne (PPE, IKE, IKZE) ma niespełna 10\% pracujących.

Obywatele nie są na tyle świadomi, aby sami odkładali na swoją emeryturę. Wiele badań ekonomii behawioralnej dowodzi, że skuteczniejszy jest program, w którym każdy pracownik zapisany jest „domyślnie”, a składki pobierane są przez pracodawcę. W takiej sytuacji większość zatrudnionych weźmie w nim udział, ponieważ większa część społeczeństwa nie jest zainteresowana polityką, reformami społeczno-gospodarczymi i będzie niedoinformowana w tym zakresie (Krzemień, 2018), nie będą też wiedzieli o możliwości wypisania się z programu lub w ogóle o samym programie.

\subsection{Zaufanie do państwa}

Emerytura w wielu wypadkach jest dla większości ludzi kwestią odległej przyszłości. Dla osób wchodzących na rynek pracy stanowi perspektywę około 40 lat. 
$\mathrm{Z}$ tego powodu wszelkie zmiany przepisów powinny być wprowadzane bardzo ostrożnie, aby nie podważyć zaufania obywateli do systemu. Powodzenie nowego programu będzie bowiem zależeć od zaufania obywateli do państwa. System powszechnych emerytur w Polsce nie ma nawet 100 lat (ZUS został utworzony w 1934 roku), dodatkowo niezwykle często w jego funkcjonowaniu następują zmiany. W ciągu ostatnich dwóch dekad nastąpiło pięć poważnych, wręcz rewolucyjnych zmian: reforma emerytalna z 1999 roku (III filar), dwie zmiany wieku emerytalnego, częściowa nacjonalizacja OFE i jego całkowita likwidacja, a aktualnie projekt PPK (nie wspominając już o mniejszych zmianach i licznych przywilejach i wyjątkach dla różnych grup zawodowych). W takiej sytuacji zaufanie do kolejnego programu rządowego będzie znikome.

Obecny rząd zapewnienia, że tym razem na pewno będą to prywatne pieniądze oszczędzających, jednak społeczeństwo pamięta poprzedni „wybitny” program OFE, z którego kilka lat temu PSL i PO zabrało środki w wysokości $152 \mathrm{mld}$ zł i potocznie mówiąc, środki te zostały skonsumowane. Przekazane na OFE składki znacjonalizowano z powodu rosnącej dziury budżetowej, a także dlatego, że OFE okazały się mało wiarygodne. Tylko niewielka część tych pieniędzy przekazanych do budżetu z OFE została zapisana na wirtualnych kontach w ZUS (Rozwadowska, 2018).

Społeczeństwo nie ma żadnych gwarancji, że przy najbliższej okazji politycy nie sięgną po zgromadzone w PPK pieniądze - zwłaszcza w momencie bardzo prawdopodobnego kolejnego kryzysu następny rząd, za zgodą Sądu Najwyższego, może ponownie uznać, że są to jednak ,środki publiczne”. Po poczynaniach dwóch ostatnich rządów trudno będzie przekonać społeczeństwo, że zasady PPK pozostaną niezmienne w perspektywie pięciu, a co dopiero 40 lat. Dotychczas ani obecny, ani poprzedni rząd nie dał zbyt wielu powodów, aby mu ufać (Krzemień, 2018). Oszczędzającym w OFE mówiono, że są to ich pieniądze, natomiast po wyroku Trybunału Konstytucyjnego okazało się zupełnie inaczej. W tej sytuacji państwo utraciło swą wiarygodność, przez co społeczeństwo będzie się obawiać, że w każdym momencie ich oszczędności emerytalne mogą zostać skonfiskowane.

Akceptacja zasad PPK przez społeczeństwo jest obecnie bardzo dużym wyzwaniem, gdyż każdy obywatel, który będzie rozważał oszczędzanie w PPK, będzie brał pod uwagę los OFE. Odbudowa zaufania do państwa (w kwestii systemu emerytalnego) może być niezwykle trudna. Dlatego aby potwierdzić odpowiedzialność państwa za złożone niegdyś obietnice, premier zaproponował, aby oddać $75 \%$ aktywów funduszy emerytalnych obywatelom, przekazując je na ich prywatne IKZE. Prace nad zmianami w OFE są nadal prowadzone i wciąż obowiązuje wariant przesunięcia $25 \%$ aktywów do ZUS, a $75 \%$ na IKZE. Najpierw jednak musi wejść w życie projekt o PPK (Osiecki, Godusławski, 2018). Problem w tym, że nie każdy pracujący ma i chce mieć IKZE. 


\subsection{Największe wsparcie państwa dla najuboższych}

Uczestnicy PPK będą otrzymywać coroczną dotację od państwa w wysokości 240 zł. Dla osób dobrze zarabiających będzie to niewielki dodatek, jednak dla najuboższych, to jest osób zarabiających najniższą pensję krajową (2100zł w 2018 roku), państwowy dodatek będzie stanowił ponad jedną piątą całej rocznej składki. Ustanowienie składki na takim samym kwotowym poziomie powoduje, że ubożsi korzystają na tym bardziej niż względnie zamożni.

Biorąc pod uwagę zagadnienie efektywności w sensie doktryny Pareto ${ }^{1}$, nie można stwierdzić, czy tego rodzaju zmiany są dobre, czy złe, nie dokonując oceny wartościującej dobrobytu rozmaitych ludzi. Zwolennicy ekonomii dobrobytu twierdzą, że równość opiera się wyłącznie na czystych sądach wartościujących, dlatego należy oddzielić kwestie równości od kwestii efektywności. W gospodarce istnieje nieskończona liczba wariantów „efektywnej w sensie Pareto” alokacji zasobów, które różnią się od siebie ze względu na podział dobrobytu. Warto podkreślić, że wiele konkretnych realokacji poprawia położenie jednych, pogarszając jednocześnie los innych.

Proponowane zmiany negatywnie ocenia „Solidarność”. Według Bogdana Kubiaka, zastępcy przewodniczącego Komisji Krajowej NSZZ „Solidarność”, wprowadzane rozwiązania są sprzeczne z zasadą solidarności społecznej, gdyż oszczędzający nie będą mieli gwarancji dożywotniej wypłaty świadczenia (Wiktorowska, 2018a).

\subsection{Kolejne obciążenie dla budżetu}

Rząd zapewnia, że obecnie budżet państwa ma nadwyżkę, jednak za dwa-trzy lub pięć lat można spodziewać się następnego spowolnienia gospodarczego na świecie. Polski rząd zamiast równoważyć budżet i spłacać zadłużenie (jak na przykład Niemcy czy Czechy), planuje kolejne koszty, bez zmniejszania wydatków w innych obszarach. Wysokość dopłat do PPK można zmienić rozporządzeniem, w takiej sytuacji mogą one zostać najpierw zmniejszone, a następnie zlikwidowane przy spowolnieniu gospodarczym (Krzemień, 2018).

\subsection{OFE vs. PPK}

Wprowadzenie OFE znacząco podniosło koszty pracy i doprowadziło do zatrudniania pracowników na tak zwane umowy śmieciowe lub na czarno. Od samego początku fundusze te były pomysłem nieudanym i skonstruowanym tak, aby przynosiły zysk dla instytucji finansowych, ponadto miały bardzo wysokie koszty

${ }^{1}$ Alokacja jest efektywna w sensie Pareto, jeżeli nie istnieje możliwość takiej zmiany, która uczyniłaby sytuację niektórych członków społeczeństwa lepszą bez pogarszania położenia innych. Natomiast jeżeli alokacja jest nieefektywna, to przez odpowiednią jej zmianę można osiągnąć korzyść w sensie Pareto, to znaczy — polepszyć położenie jednych bez pogarszania sytuacji innych. 
własne, co sprawiło, że perspektywa ich wypłacalności nie była zbyt optymistyczna. Były niekonkurencyjne i nie przyniosły emerytom korzyści z uwagi na brak możliwości lokowania środków za granicą, jako że obowiązywał nakaz lokowania większości środków w obligacje Skarbu Państwa oraz „horrendalne” opłaty.

Fundusze PPK będą mogły lokować do 30\% środków za granicą (w krajach UE i OECD), co dopuszczają regulacje unijne, nie będzie też wymogu inwestowania w konkretne produkty. Takie rozwiązanie funkcjonowało w odniesieniu do OFE. Także w zależności od wieku uczestników PPK będą miały różne profile ryzyka, co jest założeniem dość kontrowersyjnym, kiedy chodzi o przyszłe emerytury. Rząd jednak woli, aby oszczędności z PPK w pierwszej kolejności zasiliły polski rynek i tutejsze firmy, tym samym rozwijając polską gospodarkę, a nie finansowały obce rynki. Patrząc jednak z perspektywy uczestnika PPK, należy zauważyć, że polski rynek nie oferuje wielu instrumentów finansowych (przykładem jest sytuacja giełdy po odcięciu dopływu środków z OFE).

Wielu ekonomistów uważa, że powinna być większa szansa inwestowania w obligacje oraz akcje amerykańskich i europejskich firm. Dywersyfikacja zagraniczna ma duże znaczenie, aczkolwiek jest ryzykowna, gdyż obejmuje ryzyko walutowe, konieczność znajomości rynków itp. Istotnym argumentem ograniczenia inwestycji w zagraniczne firmy jest fakt, że według rządowego projektu system wspierany jest przez państwo sumą około $2,5 \mathrm{mld}$ zł rocznie, z czego większość kosztów poniesie Fundusz Pracy, co powoduje, że w interesie rządu jest, aby środki z PPK w pierwszej kolejności zasilały polską gospodarkę.

Wejście w życie ustawy stanowi duże wyzwanie dla KNF. Ustawa nakazuje bowiem instytucjom finansowym biorącym udział w programie, aby miały fundusze zdefiniowanej daty. Część z nich będzie zatem zmuszona je utworzyć i przejść przez proces rejestracji w KNF.

Korzystnie w porównaniu do OFE wypadają opłaty za zarządzanie, które nie przekroczą $0,6 \%$ wartości aktywów w skali roku, co oznacza, że jest to o wiele niższy poziom opłat niż pobierany przy innych produktach na rynku. Mimo to rząd oczekuje, że rynek przygotuje ofertę dla oszczędzających w PPK. Instytucje finansowe będą więc zmuszone zainwestować w ten produkt, zanim stanie się rentowny — pytanie, czy będą nim zainteresowane (Osiecki, Godusławski, 2018).

\subsection{Pracodawcy zadecydują o tym, w jakim funduszu będziemy oszczędzać}

W wypadku OFE była możliwość wybrania funduszu. Obecnie tę decyzję podejmie za pracownika jego pracodawca. Przedstawiciele PPK nie będą mogli zachęcać firm do zmiany funduszu — ustawa zakazuje przyjmowania korzyści majątkowych w zamian za zapisanie do konkretnego funduszu. Możliwość pozyskania za jednym razem kilku tysięcy klientów regularnie odprowadzających składki stwarza jednak olbrzymią zachętę korupcyjną (Krzemień, 2018). 


\subsection{Dopływ pieniędzy na rynek kapitałowy - wsparcie dla gospodarki i rynków, które straciły kapitał dostarczany przez OFE}

De facto wprowadzenie PPK ma dwa cele. Pierwszym z nich, tym najbardziej nagłaśnianym, jest budowanie zaplecza finansowego na starość, które ma zapewnić bezpieczeństwo finansowe i dobrą jakość życia na emeryturze. Szczególnie ważne jest to dla osób będących obecnie przed 40. rokiem życia, których świadczenia emerytalne będą niskie. Dzięki temu programowi państwo pragnie jednak osiągnąć także długofalowe efekty gospodarcze.

PPK ma ożywić lokalny rynek kapitałowy i go wzmocnić, żeby stał się silnym centrum finansowym Europy Środkowo-Wschodniej. Zadaniem PPK jest także poszerzenie bazy inwestorów lokalnych i spowodowanie napływu długoterminowego kapitału, co jest kluczowe dla finansowania inwestycji i innowacji. W dłuższym okresie ma to zmniejszyć uzależnienie kraju od napływu kapitału z zagranicy i tym samym wzmocnić stabilność ekonomiczną. Środki z PPK trafią na polski rynek kapitałowy, dzięki czemu skorzystają na nich krajowe firmy emitujące akcje i obligacje.

Pozyskanie kapitału tańszego niż kredyty bankowe da firmom szansę na szybszy rozwój, jednak nijak się to ma do zapewnienia o przyszłych emeryturach. Oczekuje się, że dzięki PPK w ciągu dekady pojawi się od 150 do 300 mld zł dodatkowych środków, które „nakręcą” polską gospodarkę, wzmocnią sektor przedsiębiorstw i przyczynią się do wzrostu dochodów. Celem tak zwanego planu Morawieckiego jest dogonienie krajów Europy Zachodniej w poziomie wysokości dochodów i jakości życia w ciągu najbliższych kilkunastu lat (Osiecki, Godusławski, 2018).

\subsection{Większość społeczeństwa straci na reformie, dopłacając do PPK w formie wyższych podatków}

Dopłaty do PPK państwo sfinansuje z podatków, w związku z czym większość osób obecnie pracujących przez wiele lat będzie na PPK więcej traciło niż zyskiwało. Przykładowo osoby w wieku 50 lat do końca życia będą płacić wyższy VAT oraz inne podatki niezbędne do sfinansowania dopłat rządowych, a ich korzyści, jak otrzymywanie wyższej emerytury z PPK, będą ograniczone ze względu na krótki okres oszczędzania. Dopiero osoby urodzone w latach dziewięćdziesiątych XX wieku odniosą korzyści. Ponadto zyski z PPK będą większe wraz z dłuższym czasem oszczędzania, a także przy wyborze wypłaty emerytury w formie dożywotniej, a nie przez dziesięć lat (JB, 2018b).

Według ekspertów GRAPE 74\% społeczeństwa straci na wprowadzeniu PPK (w tym 96\% emerytów), a korzyści będą mogły odnieść — jak już wspomniano dopiero osoby urodzone w latach dziewięćdziesiątych XX wieku. Dopłaty (powi- 
talna i roczne) generują koszty fiskalne, które będą musiały zostać sfinansowane przez podniesienie podatków. Dodatkowe obciążenia fiskalne wymuszą podniesienie VAT o 0,7\% (Wilkowicz, 2018).

\subsection{Kary dla przedsiębiorców}

Organizacje pracodawców skrytykowały pomysł karania przedsiębiorców za niezałożenie PPK. Projekt ustawy zakłada, że jeśli podmiot zatrudniający uporczywie lub złośliwie uchyla się od obowiązków założenia PPK, podlega karze. W opinii ekspertów kara (grzywny, ograniczenia wolności lub pozbawienia wolności do dwóch lat) jest nieadekwatna do skali przewinienia. Z kolei Związek Rzemiosła Polskiego (ZRP) zwrócił uwagę, że dla małych firm już sam obowiązek założenia PPK jest karą. Bogusława Nowak-Turowiecka, ekspert ubezpieczeniowy z ZRP, sądzi, że projekt PPK nie tylko zwiększy koszty zatrudnienia, lecz skomplikuje także sytuację rzemieślnika. Rzemieślnicy szkolący uczniów zatrudniają ich na podstawie umowy o pracę, a więc będą mieć obowiązek założenia PPK — nikt nie wziął pod uwagę, że uczeń w przyszłości może nie chcieć pracować w Polsce (Wiktorowska, 2018a).

\subsection{Niższe pensje i wzrost kosztów pracy dla pracodawcy}

Składka na PPK będzie finansowana przez pracodawcę i pracownika. Z programem PPK wiążą się zatem istotne koszty oszczędzania — składka pochłania część wynagrodzenia, a to oznacza niższą płacę, to jest pracownik przy tej samej pensji brutto (na umowie) otrzyma mniej netto (na rękę); dodatkowo koszty pracodawcy będą wyższe. $Z$ uwagi na niskie płace w Polsce pracownikom z minimalnym wynagrodzeniem (pensja minimalna) niezwykle trudno będzie zdecydować się na oszczędzanie w PPK, gdyż udział w tym programie będzie oznaczał dla nich mniejszy zarobek (spadek pensji netto) o $42 \mathrm{zł} \mathrm{od} \mathrm{ich} \mathrm{minimalnego} \mathrm{wynagrodze-}$ nia netto, co będzie dla nich bardzo dużym wydatkiem. Jeśli weźmiemy wartość przeciętną wynagrodzeń w Polsce, która wynosi około 3,5 tys. zł brutto, oznacza to o 70-90 zł mniej w skali miesiąca; w skali roku daje to już około $1000 \mathrm{zł} \mathrm{mniej}$ na bieżące wydatki. Nie wszystkich będzie na to stać.

Rząd zakłada, że 75\% pracujących przystąpi do programu, i jednocześnie szacuje, że obciążenie dla firm w ciągu dziesięciu lat od wejścia w życie ustawy będzie stanowić 45,3 mld zł, to jest $22 \mathrm{mld}$ zł dla dużych firm oraz 23,3 mld zł dla sektora MSP. Nieco innego zdania w tej kwestii jest Łukasz Kozłowski, główny ekonomista Pracodawców RP, który uważa, że reforma „zwiększy koszty pracodawców i może spowolnić wzrost wynagrodzeń pracowników" (Szymański, 2018). Pracownicy automatycznie zapisani będą decydowali się na wycofanie z programu, gdyż oczekiwania pracowników są oceniane na podstawie wynagrodzenia netto, które będą otrzymywać. Zagrożenie dla programu stanowi obecnie korzystna sy- 
tuacja na rynku pracy i wzrost funduszu wynagrodzeń, z którego część przyrostu będzie teraz przeznaczane na składkę dla pracowników. Ponadto w 2019 roku może zostać zlikwidowany limit składek na ZUS (nad ustawą pracuje Trybunał Konstytucyjny), co zwiększy koszty pracodawców. Przedsiębiorcy na początku 2019 roku spotkali się z kumulacją wzrostu kosztów. Nagromadzenie tych kosztów stanowi poważne zagrożenie. Nie muszą oni zatem chcieć współpracować z rządem przy zakładaniu PPK. Wejście w życie programu od 1 lipca 2019 roku było zbyt krótkim okresem. W opinii Kozłowskiego wielu pracowników nie będzie mogło sobie pozwolić na dodatkowe oszczędzanie na emeryturę, co z kolei podważa szansę realizacji scenariusza zakładanego przez rząd, że około 75\% osób objętych programem w nim pozostanie (Szymański, 2018).

Ustawę skrytykowała większość ośrodków pracodawców, a także ZUS. Podobne opinie wyrażali specjaliści BZ WBK (obecnie Santander). Według nich „składka po stronie pracodawcy spowoduje wzrost kosztów pracy o ok. 3-8 mld zł rocznie”. Zwrócili również uwagę na tę samą kwestię co Kozłowski, ,że wprowadzenie PPK zbiegnie się w czasie ze zniesieniem limitu 30-krotności podstawy składki emerytalnej, co dodatkowo podniesie koszty pracy o ok. 1 mld zł w skali rocznej”. W sytuacji braku siły roboczej i presji na wzrost płac będzie to miało wpływ na szybszy wzrost inflacji (Szymański, 2018). Wzrost kosztu pracy spowoduje natomiast, że pracodawca w pierwszej kolejności będzie zwalniał osoby uczestniczące w PPK, aby w ten sposób obniżyć wzrost kosztów swojej działalności.

Większość społeczeństwa nie ma świadomości, jakie konsekwencje dla ich wynagrodzenia będzie miało uczestnictwo w tym programie, pracodawca powinien ich zatem o tym poinformować, a rząd powinien przygotować odpowiednią kampanię informacyjną. Według wiceprzewodniczącej OPZZ Wiesławy Taranowskiej z programu nie wypiszą się osoby dobrze zarabiające, gdyż dla nich będzie to dodatkowa forma oszczędzania. Według niej jedyną zaletą systemu jest jego dobrowolność, możliwość wyjścia z programu (Oszczędzanie..., 2018).

Podobnego zdania jest Dorota Duli z Business Centre Club — według niej PPK stanowią ,,bardzo istotny koszt dla pracodawcy”, zwłaszcza w sytuacji rynku pracownika i presji na podnoszenie wynagrodzeń. Ten wzrost szacuje się w granicach 6-7\% (Oszczędzanie..., 2018).

PPK są niczym innym jak nowym podatkiem płaconym przez przedsiębiorstwa, wprowadzonym pod przykrywką zapewnienia obywatelom lepszego życia na emeryturze. Najpierw jednak odbiera się społeczeństwu ich oszczędności z OFE, aby potem stworzyć OFE-bis pod inną nazwą. Nowy system ma uzdrowić ZUS, należy zatem zadać pytanie: kiedy pieniądze z PPK zostaną przetransferowane do ZUS, aby zagwarantować minimalne emerytury, zwłaszcza że od dłuższego czasu oficjalnie mówi się, że ,wysokość składek na ZUS nie będzie miała żadnego wpływu na wysokość przyszłej emerytury”. Nikt z rządzących nie zastanowił się, skąd państwo weźmie pieniądze na wypłatę świadczeń socjalnych dla 
setek tysięcy ludzi, którzy nie odprowadzają żadnych składek na ubezpieczenia społeczne. Życie z 500+ nie uprawnia wszak do świadczeń emerytalnych (Nagroda Nobla..., 2017).

\section{Wnioski}

Według opinii ekspertów utworzenie Pracowniczych Planów Kapitałowych zwiększy koszty pracodawców i może spowolnić wzrost wynagrodzeń pracowników. Nie będzie to stanowiło większego problemu dla dużych firm, jednak stopniowe dołączanie do programu coraz mniejszych firm może być dużym problemem, szczególnie dla mikroprzedsiębiorstw. PPK będą dla nich nie tylko kosztem, lecz także nowym obowiązkiem. Zgodnie z projektem ustawy firma zatrudniająca przynajmniej jedną osobę, za którą odprowadza składki do ZUS (na ubezpieczenia emerytalne i rentowe), powinna utworzyć PPK.

Wdrożenie PPK będzie wymagało między innymi wyboru odpowiedniej instytucji finansowej, podpisania z nią umowy, podpisania z pracownikiem dokumentów i odprowadzania składek za zatrudnionych, co często będzie pociągało za sobą odbywanie odpłatnych konsultacji prawnych. Nowe rozwiązania projektu reformy emerytalnej stworzą po ich wprowadzeniu liczne problemy i utrudnienia dla podmiotów prowadzących działalność gospodarczą.

Mimo że program adresowany jest do najmniej zarabiający, to jednak oni właśnie będą mieli największy dylemat przy podejmowaniu decyzji o dodatkowym oszczędzaniu na emeryturę. Ze względu na małą wiarygodność dotychczasowych rozwiązań emerytalnych problemem we wdrożeniu PPK może stać się nieufność pracowników do nowych rozwiązań kapitałowych. Dlatego też ich wdrożenie nie rozwiąże problemu niskich świadczeń emerytalnych, gdyż pracownicy o niskich dochodach niewątpliwie podejmą działania mające na celu uniknięcie PPK.

Trudno również nie zgodzić się z opinią większości ekspertów, że samo skierowanie dodatkowych środków na rynek kapitałowy nie musi przełożyć się na przyspieszenie wzrostu gospodarczego; jest to tym bardziej prawdopodobne, jeśli uwzględni się, że naliczanie składek do PPK może skutkować minimalizacją realnego znaczenia kapitałów generowanych dzięki planom kapitałowym całej gospodarki. Nie bez znaczenia jest także negatywne oddziaływanie zaproponowanych rozwiązań na wzrost gospodarczy, gdyż program będzie dużym obciążeniem dla budżetu państwa - wzrosną koszty pracy, spadną płace, co spowoduje żądania związków zawodowych o ich podwyżkę, a jeżeli nie będzie miała ona pokrycia w wydajności pracy, doprowadzi do wzrostu cen i kolejnych żądań płacowych.

Można przyjąć (na podstawie zastosowanych w analizie metod badań jakościowych) hipotezę, że ze względu na obiektywne uwarunkowania wprowadzenia PPK, które wymagają przygotowania odpowiednich narzędzi i infrastruktury ze strony PFR, a szczególnie dłuższego czasu, że wraz z wejściem w życie ustawy 
o PPK (2019) wprowadzone zostało dłuższe vacatio legis dla niektórych zawartych w niej rozwiązań. Odrębną kwestią jest samo przyjęcie ustawy o pracowniczych funduszach kapitałowych (,nowej” reformy emerytalnej) przez społeczeństwo (pracodawców oraz pracowników i reprezentujące ich związki zawodowe). Co ważne, kontrowersyjne rozwiązania zawarte w projekcie tego aktu prawnego nie spotkały się z pozytywnym odzewem oraz poddane zostały w mass mediach uzasadnionej krytyce obu stron.

\section{Bibliografia}

Boratyński, W. (28.08.2018). Emerytura 2019 - Rząd podjął decyzję o zmianach. PPK potwierdzone! Super Biznes. Data dostępu: 26.10.2018, https://superbiz.se.pl/wiadomosci/emerytura-2019-rzad-podjal-decyzje-o-zmianach-ppk-potwierdzone-aa-2wbQ-Jovh-otNr.html.

Ceglarz, J., Janoś, K. (4.10.2018). Rewolucja emerytalna coraz bliżej. Sejm przyjął ustawę o Pracowniczych Planach Kapitałowych. Money.pl. Data dostępu: 7.10.2018, https://www.money. $\mathrm{pl} /$ gospodarka/wiadomosci/artykul/rewolucja-emerytalna-coraz-blizej-sejm,223,0,2417887. html.

Emerytury po 1000 zł dla każdego — tak PiS przygotowuje się do ratowania systemu emerytalnego (15.09.2017). Gazeta.pl. Data dostępu: 26.10.2018, http://wiadomosci.gazeta.pl/wiadomosci/ 7,114884,22375910,emerytury-po-1000-zl-dla-kazdego-tak-pis-przygotowuje-sie.html.

Frączyk, J. (13.03.2017). 10 tysięcy plus dla emerytów. Plan resortu Morawieckiego bardziej zachęci biedniejszych. Money.pl. Data dostępu: 26.10.2018, https://www.money.pl/gospodarka/ wiadomosci/artykul/emerytury-10000-plus-mateusz-morawiecki,232,0,2278888.html.

JB (28.08.2018a). Nowy pomysł na emerytury. Premier wie, skąd wziąć pieniądze. Fakt.pl. Data dostępu: 7.10.2018, https://www.fakt.pl/pieniadze/finanse/pracownicze-plany-kapitalowe-nowe-emerytury-morawieckiego-rzad-przyjal-projekt/ytkj7zl.

JB (29.10.2018b). Pomysł premiera na emerytury ma sporą wadę! Większość na nim straci! Fakt. pl. Data dostępu: 31.10.2018, https://www.fakt.pl/pieniadze/finanse/pracownicze-plany-kapitalowe-wiekszosc-polakow-straci-na-ppk/7p44e4e.

Krzemień, K. (20.02.2018). Pracownicze Plany Kapitałowe - hity i kity. Goldenmark. Data dostępu: 7.10.2018, https://goldenmark.com/pl/mysaver/pracownicze-plany-kapitalowe/.

Krześniak-Sajewicz, M. (20.02.2018). Duże zmiany w IKZE: Wyższy limit, niższe opłaty dla TFI. Polska2041. Data dostępu: 21.10.2018, https://www.polska2041.pl/finanse/news-duze-zmiany-w-ikze-wyzszy-limit-nizsze-oplaty-dla-tfi,nId,2548831.

Nagroda Nobla za emerytury. Pracownicze Plany Kapitałowe (2017). Data dostępu: 31.10.2018, http://www.zasadyogolne.info/2017/11/nagroda-nobla-za-emerytury-pracownicze.html.

Ocena skutków regulacji (8.02.2018). Data dostępu: 31.10.2018, http://www.sejm.gov.pl/sejm8.nsf/ druk.xsp?nr=2811.

Osiecki, G., Godusławski, B. (19.02.2018). Pracownicze Plany Kapitałowe to zamiennik OFE? „Apeluję, by nie porównywać tych systemów” [CAŁA ROZMOWA]. Dziennik.pl. Data dostępu: 7.10.2018, http://gospodarka.dziennik.pl/emerytury-i-ofe/artykuly/569052,pracownicze-plany-kapitalowe-to-prywatne-oszczednosci.html.

Oszczędzanie na emeryturę na nowych zasadach. „Luksus nie dla wszystkich” (15.02.2018). TVN24bis. Data dostępu: 7.10.2018, https://tvn24bis.pl/pieniadze,79/pracownicze-plany-kapitalowe-komentarze-ekspertow-w-tvn24-bis, 815410 .html.

Popiołek, A., Kostrzewski, L. (5.09.2018). Rząd zmienia szczegóły reformy emerytalnej. Pracownicze plany kapitałowe w każdej firmie? Gazeta Wyborcza. Data dostępu: 7.10.2018, http://

Ekonomia — Wroclaw Economic Review 25/4 (2019)

(C) for this edition by CNS 
wyborcza.pl/7,155287,23866095,rzad-zmienia-szczegoly-reformy-emerytalnej-pracownicze-plany.html.

Pracownicze Plany Kapitałowe z Aviva Investors (2018). Data dostępu: 26.10.2018, http://bpcc.org. $\mathrm{pl} / \mathrm{pl} /$ event-coverages/pracownicze-plany-kapitalowe-z-aviva-investors.

Ratajczak, M. (5.10.2018). Pracownicze Plany Kapitałowe już pewne. Liczymy, ile można zyskać na starość z PPK. Money.pl. Data dostępu: 7.10.2018, https://www.money.pl/emerytury/wiadomosci/artykul/pracownicze-plany-kapitalowe-ile-mozna-zyskac, 23,0,2417943.html.

Rewolucja w emeryturach dla 11 milionów Polaków. Będzie dodatkowa składka (15.02.2018). TVN24bis. Data dostępu: 7.10.2018, https://tvn24bis.pl/z-kraju,74/pracownicze-plany-kapitalowe-od-2019-roku-projekt-do-konsultacji,815251.html.

Rozwadowska, A. (28.08.2018). Morawiecki: $40 \mathrm{mld}$ zł z budżetu na pracownicze plany kapitałowe. Gazeta Wyborcza. Data dostępu: 7.10.2018, http://wyborcza.pl/7,155287,23834407,morawiecki-40-mld-zl-na-pracownicze-plany-kapitalowe.html.

Rząd przyjąt projekt ustawy o Pracowniczych Planach Kapitałowych (28.08.2018). Bankier.pl. Data dostępu: 26.10.2018, https://www.bankier.pl/wiadomosc/Rzad-przyjal-projekt-ustawy-o-Pracowniczych-Planach-Kapitalowych-4152621.html.

Rzadowy projekt ustawy o pracowniczych planach kapitałowych (4.09.2018). Druk nr 2811. Data dostępu: 26.10.2018, http://www.sejm.gov.pl/sejm8.nsf/druk.xsp?nr=2811.

Skąd wziać pieniądze na emerytury? Morawiecki rozważa rewolucję (16.02.2018). Newsweek. Data dostępu: 7.10.2018, https://www.newsweek.pl/polska/spoleczenstwo/premier-1000-zlotych-dla-emeryta-to-uzdrowi-system/h5890ld.

Szymański, D. (19.02.2018). Jedna kwestia w reformie emerytalnej powinna szczególnie zaniepokoić pracodawców. Business Insider. Data dostępu: 7.10.2018, https://businessinsider.com. $\mathrm{pl} /$ firmy/podatki/reforma-emerytalna-pis-a-wzrost-kosztow-pracowniczych-ppk/ygg49hg.

Wiktorowska, B. (19.03.2018a). PPK nie takie dobrowolne. Oto lista zastrzeżeń związków i pracodawców. Gazeta Prawna. Data dostępu: 26.10.2018, https://serwisy.gazetaprawna.pl/emerytury-i-renty/artykuly/1111817,zastrzezenia-zwiazkow-i-pracodawcow-do-ppk.html.

Wiktorowska, B. (29.03.2018b). Bogatsi emeryci mają się podzielić z biedniejszymi. Gazeta Prawna. Data dostępu: 26.10.2018, http://serwisy.gazetaprawna.pl/emerytury-i-renty/artykuly/1114232,emerytura-obywatelska-dla-najbiedniejszych.html.

Wilkowicz, Ł. (26.10.2018). 74 proc. ludzi traci na wprowadzeniu PPK [ANALIZA]. Forsal. Data dostępu: 1.11.2018, https://forsal.pl/artykuly/1319931,74-proc-ludzi-traci-na-wprowadzeniu-ppk-analiza.html.

Ekonomia - Wroclaw Economic Review 25/4 (2019)

(C) for this edition by CNS 